\title{
Does House Ownership Entail Economic Empowerment among the Low-Income People In Zambia?
}

\author{
Christcola Basila $^{1^{*}}$, Kennedy Sialoombe ${ }^{2}$ \\ ${ }^{I}$ Department of Social Sciences, Chalimbana University, Chongwe, Zambia \\ ${ }^{2}$ Dag Hammarskjöld Institute for Peace and Conflict Studies, Copperbelt University, Kitwe, Zambia \\ *Corresponding Author: Christcola Basila, Department of Social Sciences, Chalimbana University, \\ Chongwe, Zambia
}

\begin{abstract}
In 1996 Zambia formulated a comprehensive housing policy aimed at the provision of adequate and affordable housing, especially for the low low-income groups. This study assesses whether the ownership of houses has helped people improve their houses and their economic status. It employs a qualitative methodology. The Alternative Development and Gender and Development (GAD) theories underpin the analysis of the study results. The privatisation of housing has both positive and negative effects on the poor. Some house owners' economic status or security have improved to some extent due to ownership of a house. They are now able to make savings, resale the house, sublet it or trade at home. However, privatisation of houses denied some people of their rights hence became disempowered since they could not afford to purchase their houses. During the privatisation of houses, the government did not put measures to help the poor realise their housing rights. Thus, owning a house did not provide a sustainable solution to economic insecurity neither did it lead to meaningful economic empowerment as people did not participate in the decision-making process.
\end{abstract}

Keywords: Home-ownership, economic empowerment, Gender and Development (GAD), Alternative Development, privatisation, housing scheme, participation, housing rights, human rights.

\section{INTRODUCTION}

In Zambia, the housing need is enormous. The housing deficit is estimated to be at about two million (Lungu, 2018). This shows that many people need adequate housing in the country. Following the substantial housing needs, the government of Zambia came up with a strategy through the formulation of the 1996 housing policy to solve this problem. The government is currently reviewing the policy to respond to the current housing needs. House/home-ownership, which is the focus of this study, is one of the outcomes of the 1996 housing policy. This was through the sale of public rental houses. Other outcomes included attempts to build new houses for sale to those who can afford. This was also a way of trying to revive the housing construction industry; and allocation of serviced plots in housing development areas for people who can build their own houses. This study investigates the effects of the housing scheme in helping low-income groups realise their rights and economic empowerment through the acquisition of houses in Mufulira town on the Copperbelt province of Zambia.

\section{RESEARCH AIM}

The study aims to investigate the effects of Zambia's housing empowerment scheme in empowering the majority of the people economically, particularly the low-income men and women in Mufulira town through the sale of public rental houses to the sitting tenants. Thus, the study attempts to find out the relationship between house/home-ownership and economic empowerment.

\section{RESEARCH QUESTIONS}

How has house ownership improved economic status of low-income people?

Has ownership of houses helped the people improve their houses?

\section{BACKGROUND OF THE STUDY}

\subsection{Understanding House/Home-Ownership}

A house is a physical building, while a household is defined as a group of persons who usually cook, eat and live together and regard one person as the head of the household. The presence of a family - 
children and parents, including relatives - and the activities of family life make a house into a home (Central Statistical Office, 2015; Saunders, 1990). In this study, a home or house is a place where one lives permanently, especially with one's family, or as a member of a household. According to Blunt and Varley (2004), a home is a space of belonging and alienation, intimacy and violence, desire and fear. It is invested with meanings, emotions, experiences and relationships that are very cardinal in people's lives. Thus, house/homeownership implies owning a house where one lives with his/her family.

\subsection{The Role of Home Ownership}

The expansion of the number of house owners remains a national priority in most countries because home-ownership is at the root of good citizenship. This is because it plays a vital role in creating stable neighbourhoods and helping families build real wealth, no matter where they live and their income. Everyone, including women, should have the opportunity to own their own homes. Homeownership strives to expand self-sufficiency for individuals, strengthen families, and empower communities to shape their futures and their destinies. However, the initiative to implement the Habitat Agenda faces several challenges such as poverty, disease, conflicts and wars, illiteracy, unemployment and institutional weaknesses. Additional problems are due to the difficult period of large-scale market reforms (United Nations, 2001). Unfortunately, "housing wealth is often the only source of wealth for low-income households and may carry unanticipated costs for maintenance, renovation and utilities" (André \& Dewilde, 2014, p.9). This is the case for low-income people of Mufulira.

In 1996, comprehensive housing policy was formulated, whose main goal was to provide adequate and affordable housing for all income groups in Zambia. Zambia was awarded the United Nations Centre for Human Settlements (UNCHS) 'Habitat Scroll of Honour' in 1996 for a participatory and innovative approach to the formulation of the housing policy. The significant outcomes since the adoption of the Housing policy include the sale of most government pool, council, parastatal and mine houses to sitting tenants and revival of housing construction. There is also the upgrading of the unplanned settlement in the peri-urban and rural areas done by such Non-governmental organizations (NGOs) as Habitat for Humanity Zambia (HFHZ) among others (Mbati-Mwengwe, 2001).

The focus of this study is the sale of public rental houses, particularly former council houses to sitting tenants as a way of empowering them economically. Before the sale of public rental houses, accommodation was connected to one's employment. Employers rented houses for their employees or paid housing allowance, or accommodated the employees in institutional houses. When the government of the Movement for Multi-party Democracy (MMD) came into power in November 1991, they decided to sell most of the government houses to the sitting tenants. In 1996, the government embarked on the sale of council houses, government pool houses, and mine houses to the sitting tenants either employed or not under the banner of empowering especially the low-income people.

\subsection{Housing Rights}

"Housing is a basic social need after food and clothing and, as with the other basic needs, adequate housing is a requisite to national socio-economic development. It has been noted that its inadequacy can have a severe impact on the environment, health and the general well-being of communities..." (Ministry of Local Government and Housing (MoLGH), 1996a, p.1). The relationship between housing and rights is that the securing of rights will ultimately lead to the meeting of needs. The shelter is an essential aspect of our lives. The government of Zambia strongly supports the principle of homeownership as a way of providing security, stability and economic power to the family unit as well as a basis for the development of economically active and motivated communities. However, in practice, this is not the case, as is discussed in this study.

Adequate housing affects the attainment of other rights. Inadequate housing affects the securing and maintenance of employment, threaten health, impedes education and impairs privacy. A "home is more than just a place of shelter - where we live influences every aspect of our lives" (Bergeron, 2019).

The seventh Millennium Development Goal on environmental sustainability recognizes that urban land tenure is pertinent to the urban poor (UNDP, 2003). By implication, legal ownership of a house 
is essential to ensure the quality and security of a home and neighbourhood. Possession of a house can be a precondition to acquiring other assets that support livelihoods. For instance, establishing a homebased enterprise, renting out rooms in the house to augment income, and having collateral for credit, all of which are linked to poverty reduction among the urban poor (Moser, 1998 cited in Alsop, 2004).

In Zambia, the housing scheme aimed at empowering the majority of the people with shelter as a fundamental human right. Some houses were highly subsidized and were priced according to their age and the state in which they were. Some houses were comparatively cheap, which was in line with the strategy to empower low-income people in the country (Basila, 2019; Basila, 2005). The low-income people were the majority, and most of them lived in old houses. However, the beneficiaries who were the sitting tenants were to improve and maintain the houses, especially the old, dilapidated ones by renovating, extending, and fencing around them where possible. Some government houses were not as highly subsidised as council houses. The Ministry of Finance and Economic Development (MoFED) was supposed to release the money to Zambia National Building Society (ZNBS) to be administered in the form of loan or mortgage to the sitting tenants civil servants in council or government houses. However, this was not a guaranteed facility due to lack of funds (Mbati-Mwengwe, 2001).

\subsection{Housing Empowerment in the Era of Neoliberal Policies}

The house empowerment scheme coincided with Zambia's Structural Adjustment Programme (SAP) sponsored by the International Monetary Fund (IMF) and the World Bank. Among others SAP led to the privatisation of many State-Owned Enterprises, resulting in massive job losses hence, affecting the majority of the people's income, particularly the new house owners. The adoption of neo-liberal policies, such as Structural Adjustments (SAPs), privatisation, and liberalisation in many countries, including Zambia, have affected the housing sector. Schlyter, (2000), argues that privatisation of public rental houses by selling them to sitting tenants have in many countries of the world been a reform integrated within the processes of market liberalisation and structural adjustment. Homeownership and shrinking public ownership are components of the urban housing policy in most African countries. In Zambia, the government emphasised its willingness to empower the people by making them house owners. But it was possibly intended to support the creation of a housing market. The policy was supposed to revive the housing production; in the process, it resulted in some social groups being disadvantaged. This is because the government must play a central role in ensuring that even the poorest members of society have access to housing. Through this programme, people may have benefited to some extent by owning their houses. However, the housing may become less accessible to the poor or low-income groups when privatisation assumes the role of the government in the housing sector, meanwhile, housing as a fundamental human right should be accessible to all.

There is widespread unemployment in the country after the privatisation of over 300 State-Owned Enterprises (SOEs). The companies did not give meaningful terminal benefits to many people who were declared redundant or retrenched. Some were given part payments. Most of the people had no benefits, having worked for a few years (World Bank, 2001). Some people became homeowners, but without a source of sustainable income to service, maintain and improve their new houses as most of the houses were old and dilapidated. Meanwhile, empowerment is meaningful if it provides security, stability and economic power to the family unit. Any meaningful empowerment should result in the sustainable development of people's lives. Therefore, this study attempts to explore the effects of the housing empowerment scheme in empowering the poor. According to Census Statistical Organisation (CSO) (2014), in the study area, the Copperbelt province, the level of poverty stood at 34.3 per cent in 2010 and 18.3 per cent for the extremely poor.

\section{THEORETICAL FRAMEWORK}

This section presents the theories and concepts used in the analysis of the findings. Alternative development theory and gender and development (GAD) theoretical perspectives underpin the analysis of the study findings.

\subsection{Alternative Development}

Alternative approaches to development was a response to the fading optimism brought about by modernisation and dependency theories in the 1970s. It challenged the state-centred approach to economic development, particularly in the Third World. The modernisation models failed to improve 
poor people's lives. Thus, there was a need to rethinking the approaches to development (Saffari, 2013; Friedmann, 1992).

Alternative development is juxtaposed against mainstream development. It involves a range of contemporary strategies to develop the global South. Strategies of alternative development are usually developed and implemented by a network of international financial institutions and international and non-governmental organizations. However, for most development projects, you need state involvement. The state usually takes up the role of facilitation, such as through passing relevant legislation. Alternative development focuses on human development, gender and empowerment (Saffari, 2013). For example, it argues that if social and economic development means anything at all, it must mean a definite improvement in the conditions of life and livelihoods of ordinary people. It is morally wrong for large numbers of people to be systematically excluded from development.

Pieterse (2001) states that alternative development is concerned with achieving development by empowering the people through participation to enable them to meet their basic needs and rights as well as considering gender issues. Just like participation, the concept of empowerment is equally central to alternative development. Empowerment is a highly contested concept and means different things for different people. Empowerment is a process through which people take control over their own lives, gain the ability to do things and make their own decisions that will improve their lifestyles (Chattopadhyay, 2018, Young 1987 in Visvanathan, et al. 2000).

The elements of empowerment such as economic, social and political, are essential in discussing how the sale of public rental houses have impacted on people's lives in Zambia, particularly the lowincome Mufulira residents. However, this study focuses on economic empowerment. Social and political empowerment will be investigated in another study.

\subsection{Gender and Development (GAD)}

GAD falls under 'Theories of women, gender and development' - which borrows ideas from both alternative development and feminism. Both alternative development theory and GAD focus on improving the welfare of the poor through meeting basic needs, self-reliance and empowerment. But GAD puts much emphasis on the empowerment of women and power relations between men and women in society.

The gender and development approach emerged in the 1980s when feminists challenged the notion that class analysis alone could explain women's oppression. They were concerned with the relationship between society's macroeconomic structures and their effects on women. GAD focuses not just on women, but on social relations between men and women, in the workplace and other settings. GAD, as a model, adopts a holistic approach and treats development as a complex process influenced by political and socio-economic forces. It recognises that household conflicts arise both from gender divisions of labour and generational differences. GAD goes beyond economic wellbeing to address individual's social and mental needs; it includes a definite role for the state in programmes to bring about equality between men and women (Sikira, al et, 2018; Visvanathan et al. 1997).

Development projects require gender-sensitive planning; such projects should aim at identifying women's and men's practical and strategic needs. Practical needs like housing are to improve the conditions of men and women in their daily struggle for a living. On the other hand, strategic needs can change the structural and legal barriers or constraints for people-centred development aimed at realising rights (Visvanathan et al. 1997). Home-ownership programmes must strengthen women's legal right to adequate housing, inheritance, protection against violence and evictions.

Domingo (2013) is discussing property rights, and gender equity argues that that ownership and control of property is potentially a contributing factor in altering the balance of power in gender relations. It contributes to economic autonomy for women. In the household, in the community or wider political society, ownership of property enhances the bargaining power of women which alters voice and access to decision-making. Developmental projects affect women and men differently. This study will show whether men and women were empowered economically in the same way or differently. 


\section{ANALYSING EMPOWERMENT THROUGH HOMEOWNERSHIP}

Empowerment is a process experienced primarily at the individual level, rather than within a group or community. The focus on the individual often assumes that collective empowerment begins with personal self-development, moving through the community as people learn and/or engage in selfempowering practices. This study looks at both dimensions of empowerments that is personal and collective. There are two forms of empowerment, economic and social. This study focuses on the former. Economic empowerment has some economic security as an individual through income generation by trading from one's home premises; subletting some houses for rent, and other business opportunities.

\subsection{Economic Empowerment}

Sikira et al. (2018) citing Batliwala (1994) and Gary (2009), posit that through empowerment, the powerless gain greater control over their life circumstances. It includes the control over resources (physical, human, and intellectual, financial) and ideology (beliefs, values and attitudes). Friedmann (1992) explains that economic empowerment is a process where people gain access to certain bases of productive household wealth, such as means of income generation. In this study, to own a house may imply to have some economic security or increase in economic power or productive power also referred to as 'power to', this kind of power creates new opportunities or possibilities for income generation. For example, the house can be a source of income. This can be through various means that improve one's economic status such as renting out rooms/houses, trading or establishment of homebased business ventures. The realisation of people's fundamental rights may encourage people to participate more in activities that can bring about positive changes in their lives and their community at large.

\section{RESEARCH METHODOLOGY}

\subsection{Research Paradigm}

Qualitative research paradigm seeks to explore and understand the meaning individuals or groups ascribe to a social or human problem. Researchers collect data in the participant's setting (Cresswell and Cresswell, 2018). Based on this understanding, the study employed a qualitative paradigm. The nature of the study requires an understanding of the lived experiences of the homeowners. Qualitative methods through the use of in-depth interviews, focus group discussion (FGD) and simple observations enabled the study to gain a broader understanding of people's views and feelings about the effects/impacts of the home-ownership project. This approach was critical in answering the research question because issues of empowerment and rights are complex. Therefore, the need to get beyond what is seen as facts to a deeper understanding. This requires a methodology that allows a researcher to be involved in the in-depth inquiry of experiences of their respondents. The results were qualitatively analysed to bring out the main issues related to the effects of home-ownership as perceived by the home-owners and the government officials.

\subsection{Choice of the Study Area}

The programme of selling houses coincided with the privatisation of most government-owned industries or companies. This resulted in most people losing their jobs. Mufulira town in Zambia is one of the towns that have been adversely affected by the privatisation of the mines and restructuring of government departments leading to massive job losses. It was interesting to get the people's views and feelings about empowerment through housing amidst high levels of poverty in the town. It was also essential to find out whether the people after buying the houses are playing their role in improving and maintaining them.

\subsection{Sources of Data}

\subsubsection{Secondary Data}

The study obtained secondary data from the Ministry of Local Government and Housing in Lusaka, Zambia National Housing Authority, and Mufulira Municipal Council through the review of policy documents and other official reports on the sale of houses and housing programmes in Zambia. From the Central Statistical Office, the study gathered data from survey reports on housing, population and poverty. Therefore, secondary data comprised of what these organisations or departments are doing about housing in Zambia. 


\subsubsection{Primary Data}

In this study, primary data was obtained through in-depth individual interviews with the home-owners and government officials. In addition, two focus group discussions were conducted to generate information about the extent to which the sale of houses empowered people economically. During fieldwork, data on whether the tenants had made any improvements to their houses were gathered through simple observations and taking photographs.

\subsection{Key Informants}

The study obtained information from those who were able to buy houses in the low-cost residential areas in Mufulira town on the Copperbelt province of Zambia and government officials. Government officials provided primary data and official documents and reports. The government officials interviewed were from the Ministry of Local Government and Housing (MoLGH) in Lusaka and the local Authority (Mufulira municipal council). They were chosen based on their position that they would give relevant information to answer the research question.

\subsection{Sampling Technique}

In this study, 24 house-owners men and women were interviewed. Besides, two focus group discussions were conducted to augment interviews generated data. The 24 households were purposely selected from the low-income group living in low-cost housing area ( 8 houses from Chibolya, eight from Kantanshi, and another eight from Kamuchanga residential area). The other interviewees were two (02) officials from the Ministry of Local Government and housing departments and one from the Mufulira Municipal council. These were in the position to represent the government's position on the economic empowerment of the housing scheme.

\subsection{Data Processing and Analysis}

Data generation and analysis are not divorced, because, in qualitative research, analysis is an on-going process taking place even during data collection. Analysis of data is a process of bringing order, structure, and meaning to the mass of collected data. In qualitative research, analysis of data seeks to establish relationships among categories of data and explain the data in relation to theory (Cresswell, 1994; Patton, 1990). This study used a combination of different aspects of various approaches to analysis to gain a better understanding of data. Fieldwork was an essential context for the analysis of data collected. The flexibility of qualitative methods allows the researcher to be in close relation with objectives understudy and theory creates possibilities for analysing the data.

The interview generated data were transcribed by rewriting them into readable and meaningful information and also gave some interpretations to the interview notes. The preliminary analysis of data while in the field helped in seeking clarifications and missing information from respondents. Before, the writing up process, responses were grouped according to emerging themes. Then regrouping of the data was done under various themes related to the research question and coming up with final categories which were used in writing up the results. The secondary data were analysed through the use of content analysis to gain a clear understanding of the subject matter on house empowerment program.

\subsection{Evaluation of Qualitative Research}

Qualitative research can be evaluated because it needs to be more than just telling convincing stories. Hence this brings us to the issue of validity. According to Mikkelsen (1995), validity, in general, is the degree to which the findings are interpreted correctly. In qualitative research, validity is not a straight forward issue, because of people's subjectivity, due to different views over the same subject matter. In qualitative research, triangulation is a practical guideline for undertaking validation. Thus, this study used different data collection methods or techniques, such as in-depth individual interviews, group discussions, and observation. The data was gathered from both the grass-root and implementation levels.

\section{Data Presentation, Analysis and Discussion of ReSEARCh FindingS}

\subsection{House Ownership and Economic Empowerment}

To own a house may reprent some economic security or economic power, which can be experienced mainly at the individual level. In this section, the study discusses whether the home-ownership has led 
to economic empowerment among low-income men and women. Economic empowerment will be discussed under income generation through trading from house premises as well as renting out houses. The section will also look at people's ability to improve and maintain the houses they bought.

Empowerment, as already discussed in the theoretical section, refers to a process in which the poor men and women are helped to take control over their own lives by gaining the ability to do things and make their decisions that will improve their lifestyles. In this study, ownership of house provides examples of potentially empowering forms of government support for the poor to improve their economic status. Data collected through interviews revealed that most of the house owners are original sitting tenants who bought their houses from the council. Some house owners have been staying in those houses for an extended period, dating back to the 1960s. However, several house owners bought the houses from the original sitting tenants who resold their houses.

\subsection{House-ownership a Basis for Income Generation}

Some respondents in the study area pointed out that they have benefited economically through the privatisation of housing as they now own houses which are worth thousands of Kwacha in Zambian currency. They explained that though they may not have the money at the moment, they can sell a house in case of an emergency. Several authors claim that access to economic power by family units is a basis for the development of economically strong and motivated communities. Herbert et al. (2013) argue that the support for homeownership in recent decades is anchored on the idea that homeownership is an effective means of wealthy accumulating among low-income and minority households. Saunders (1990); and Retsina and Belsky (2002) adds that homeownership builds wealth and is a stable investment; also Friedmann (1992) sees an increase in a household's access to bases of its productive wealth as an increase in economic power.

The fact that the new house owners no longer pay rent has enabled them to save some income. In this way, the government, through its sale of houses, has helped the poor to have some extra income. Despite that homeowners still have to pay land-rates, some feel empowered as a result of the houseownership as they consider occupancy cheaper than renting. The extra money that families save is used to meet other necessities such as health care charges, food and education of their children. The education of children is a long term investment to empower their children to lead decent lives in adulthood. Education, even among the poor, is considered to be a means through which they can escape poverty.

According to the new house owners in Mufulira, they can now do several things to their houses which they could not do when they were tenants paying rent to the council. This shows that empowerment has given them rights over occupation, daily use, alteration, construction, design or sale. According to Harrison (1995), the owner of a house has control over investment and capital itself, in that s/he can determine whom to contract for building, renovation or extension of the house. This also means the owner can use the house for income generation through several possibilities available.

\subsection{Income Generation through Trading}

In line with Harrison's view as pointed out above, the study reveals that some house owners used their houses as a basis for income generation. For example, doing petty trading from home. This is a common phenomenon among the low-income group, and they consider owning a house a critical factor in their businesses. It is profitable and convenient as no rentals are involved. They use income generated from their petty trading on the most basic needs such as food and other necessities. Homeowners stated that they find trading from home profitable because they do not pay any fees as they would do at the market place. For example, a middle-aged woman who owns the house shown in plate 9.1, finds trading from home advantageous as she can sell and attend to home chores and hence save time. The children help in selling when they are not at school. Friedmann (1992) argues that the surplus time available to a household economy beyond what is necessary for gaining a subsistence livelihood is an essential base for social power. This is because without access to such surplus time household options are severely constrained.

It is also important to note that not only women do their income generation from home, but men also have a chance for such activities. Below is an illustration from a middle-aged man who is a house owner and a self-employed shoemaker. Since he bought a house, he has made an additional structure 
to his house and does his shoemaking and repairing from his workshop at home. The self-employed man said:

I do my business here (home) and do not need to pay money for a stand at the market place. From the time I started operating from here, I have no worries about payments towards a rented stand even when there is no business some days. While the first days of such businesses may be difficult as people need to know your existence, but in the long run when one becomes established, you do quite well as there is no competition and working hours are flexible.

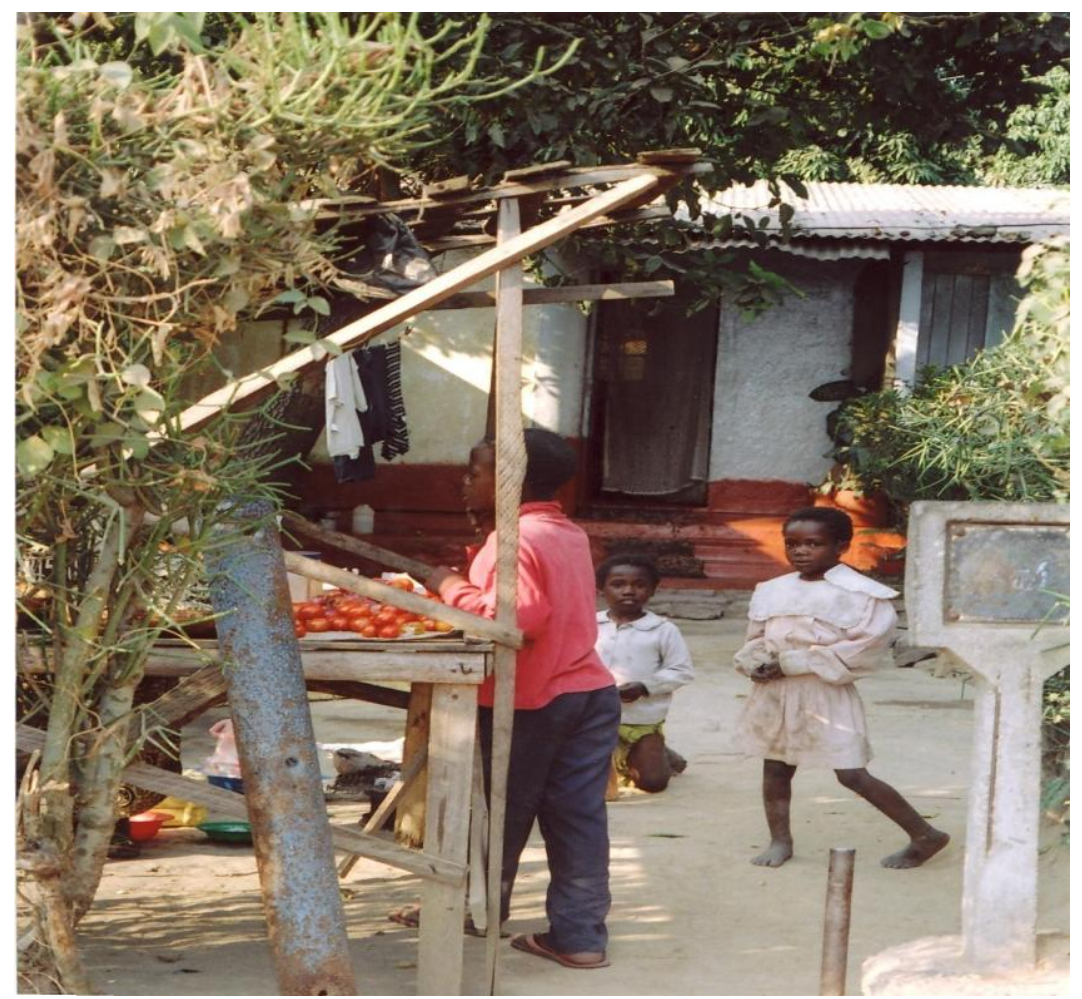

Plate9.1: Trading from home

Source: Field Photo

Since the implementation of a free market economy and privatisation in the country, people are free to carry out business ventures as they wish. Before it was prohibited to trade from a public rented house, there are now no more restrictions. Informal businesses or trading is widespread in Zambia as a consequence of neoliberal economic policies that forced many people out of formal employment.

\subsection{Income Generation through Renting}

Some house owners are not doing any trading but had to sublet their house to tenants to earn an income. There were many examples of families who had moved out of their homes - either selling or renting the house. Most commonly, they moved to a shanty compound and thus deteriorated their living conditions. Shanty compounds usually have substandard housing conditions and generally not suitable for human habitation. For example, one family revealed:

We moved into this house in 1998 when we bought the house from the person who bought it from the council. We moved to this house from another town after being retrenched. We came in the hope of finding a job. The former owner of the house has moved to Kamwama (a shanty compound within Mufulira).

Another strategy was to sublet part of the house. In an interview with another house owner, an elderly woman, it was discovered that she left the main house and is residing in a small house (an additional structure built from local normally low-quality material shown in figure 9.2). She rented out her own house to get some extra income. While the money realised from renting such low-cost houses may not be adequate for a decent living, people without options have to make ends meet with whatever they realize.

From the empirical evidence, we can see that the home-ownership programme through the sale of 
council housing was not only an empowering process but also a disempowering one for many lowincome men and women. It is difficult for low-income people to sustain their housing condition without a source of a steady flow of income. The low-income people were marginalized in the process as they had fewer opportunities for meaningful empowerment than do better-placed ones. Well-to-do people are economically powerful and have access to the 'market'. Schuler (1995) argues that in market economies, social and economic rights are framed in relation to 'access to the market' since economic and social wellbeing is derived from participation in the market. States must protect social and economic rights under international human rights law. The fulfilment of social and economic rights by states as their obligation also depends on the mechanisms that are available to citizens to defend their rights and make the state accountable. This calls for political power to influence the government to act towards enhancing the wellbeing of the poor.

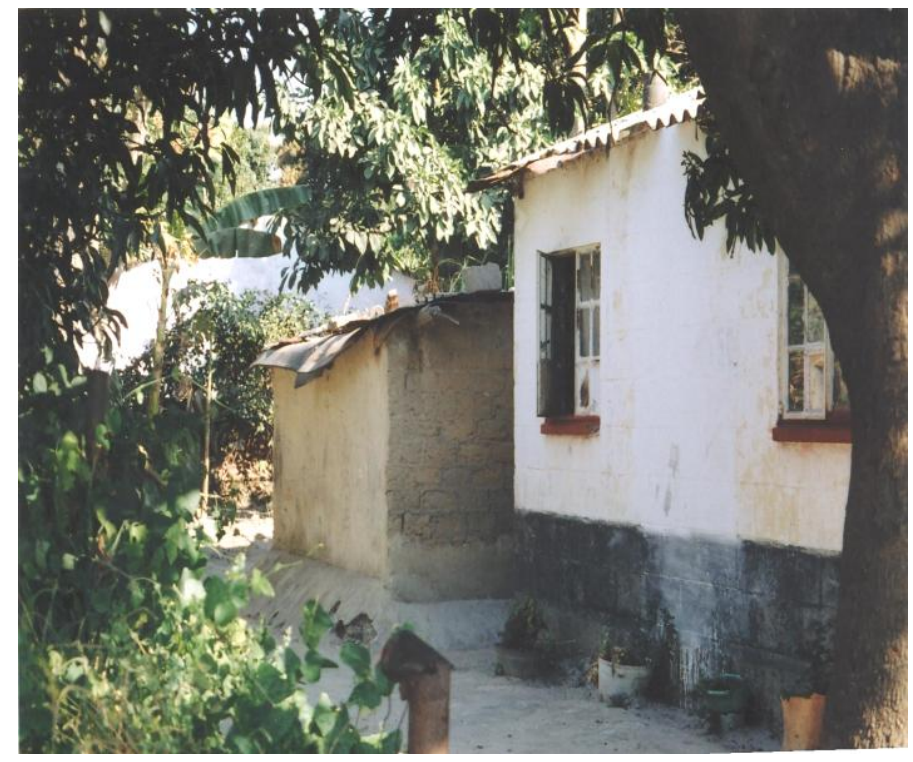

Plate9.2: Main house and an additional structure occupied by a house owner

Source: Field photo

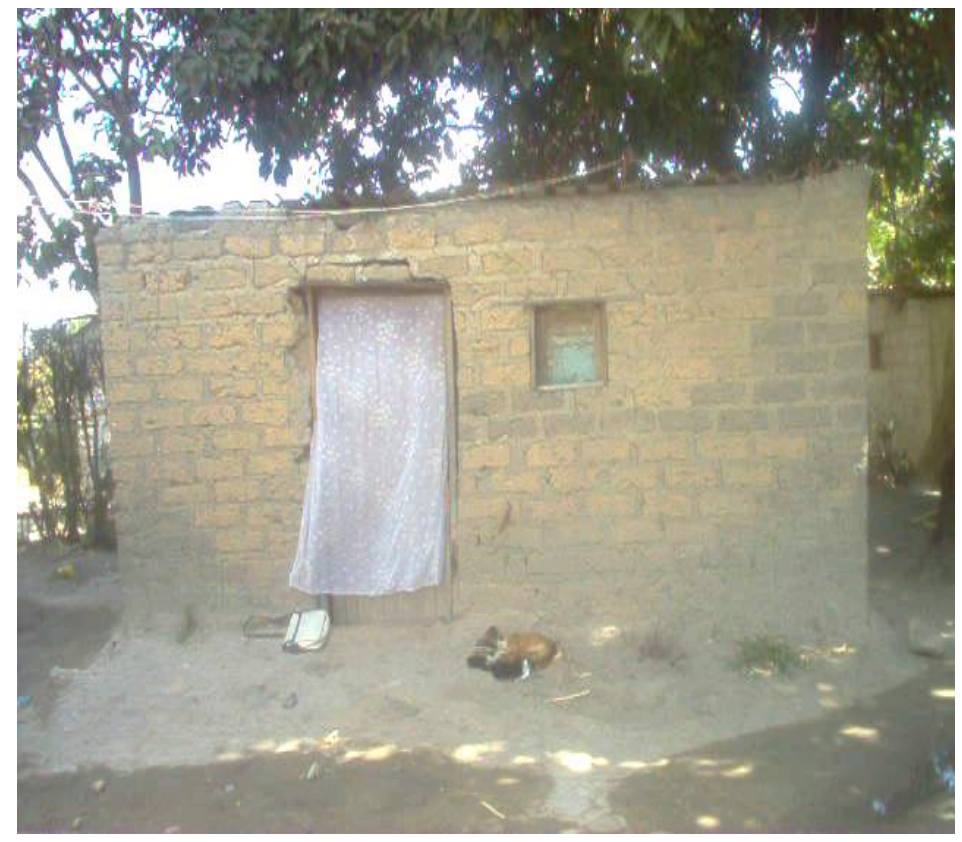

Plate9.3: Another additional structure occupied by a house owner

Source: Field photo

Although, home-ownership scheme aimed at improving people's economic status, the economic hardship is making it impossible for many of them to remain in their bought houses. Therefore, it was not surprising to discover that some have re-sold their houses to have money to solve more pressing 
problems. This lack of economic security has led many people into a predicament of homelessness. Therefore, owning a house only gives a temporary solution to the problem of economic security; it does not lead to real economic empowerment. This implies that people's economic rights can only be secured when they have stable jobs with reasonable incomes. Conversely, those with means have managed to extend their houses in order to rent out some rooms to have income, though relatively small. Although, ownership of houses seem to have improved people's economic status to some extent, rewards from most petty trading and subletting houses are too insignificant to overcome poverty among most of the low-income people in a meaningful way.

\subsection{Other Income-Generating Business Opportunities}

In order to achieve meaningful empowerment, the household would usually need access to a secure income. For example, the findings show that tenure or ownership of a house can be very empowering when enjoyed in conjunction with high and secure earnings. The freedom of ownership can enhance relative opportunities for income generation since it may be easier and profitable to run a business from home than it is under the tenancy agreement. Below is a photo (9.4) of former council house that has been turned into a nursery and pre-school. The owner of this school is a general worker under the civil service earning a low salary. However, he obtained a loan from the bank due to his creditworthiness as a permanent employee in a well-established government department. Therefore, we can safely conclude that the combination of a physical house and capital can be very impressive, as the house can become security for borrowing money for a business.

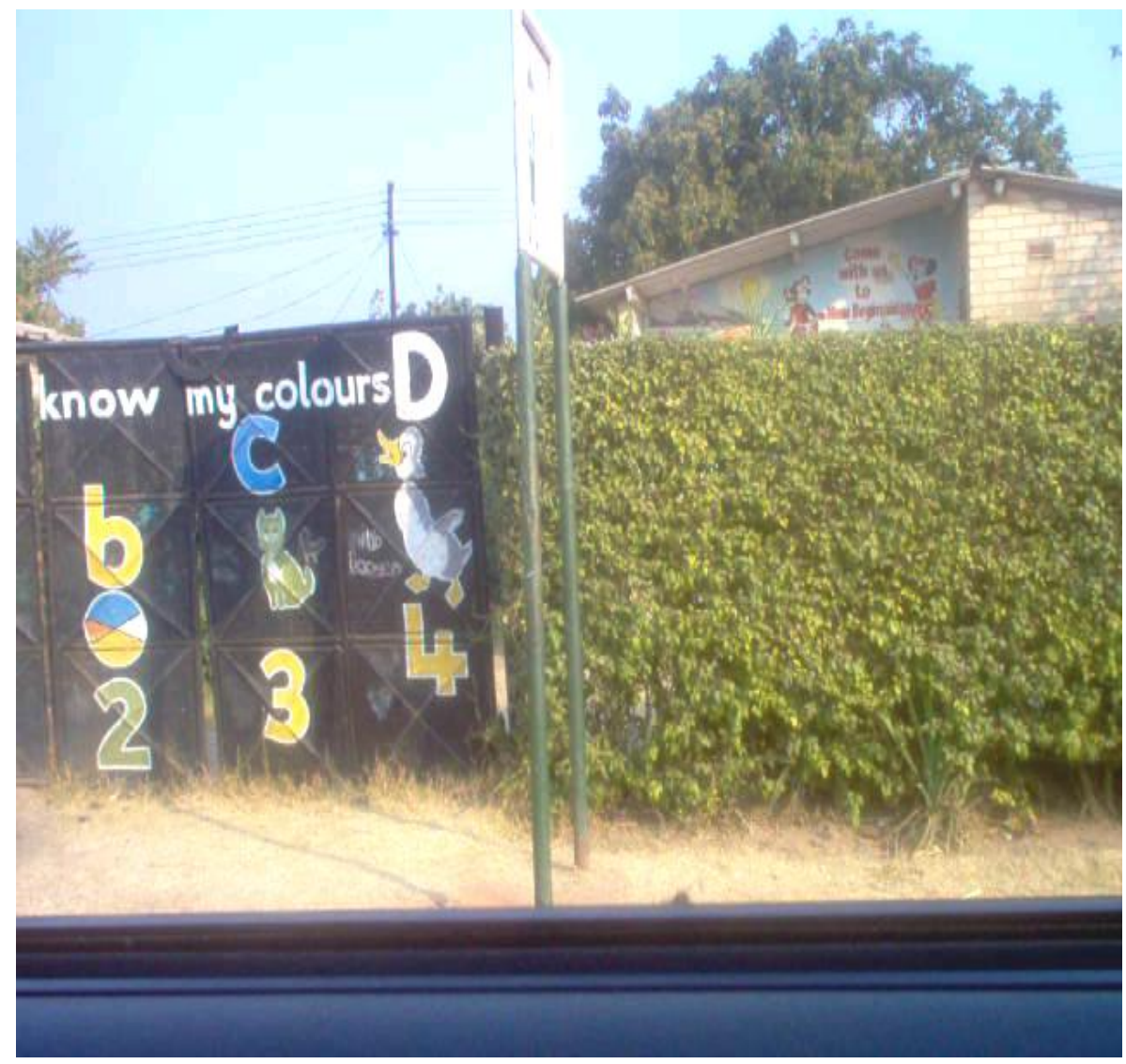

Plate9.4: Purchased House turned into a Pre-school

Source: Field Photo

The house owner in question used the borrowed money to renovate the house and buy all necessary educational materials to run his own pre-school. The family has experienced social mobility in a way as its income or wealth has increased. Hence, the study shows that men and women without steady earnings or employment have fewer opportunities for empowerment than better-placed ones.

\subsection{Economic Empowerment and Gender Relations}

Friedmann (1992) explains that surplus time is a function of many things, such as time spent on a journey to wage-paying work, the ease with which basic consumption items such as food, water, and 
fuel are obtained, the frequency of illness in the household and access to medical services, and division of labour. The low-income house owners are constrained in many of the aspects mentioned above that determine surplus time as we are going to see later in this study. According to Saunders (1990), domestic relationships have been changing with time because the number of female employees has increased in most societies. Nevertheless, among the low-income groups in Zambia, domestic work is still mainly a woman's task.

Although a large number of women leave home to do business, gender remains a crucial factor in shaping domestic activities. Many women reported that they do most of the tasks at home such as cooking, house cleaning, laundry and child-caring while men's participation in housework and parenthood is still very low. Hence, the privatisation and liberalisation of trade have helped many women to do their businesses from their homes. However, this implies that they have to generate income and attend to home chores, thereby become over-burdened. Women often become the primary breadwinners of their families as their husbands have been retrenched or forced to retire early. Hyden (1981) cited by Saunders (1990) asserts that a home is "a spatial component of their economic oppression". However, many women in the study area pointed out that it is an added advantage to trade from home rather than from the market or street as they can kill two birds with one stone. However, it is essential to emphasise that income generated from home is not very significant for reducing their poverty levels. Besides, unemployed people in Zambia do not receive any social benefits.

On the other hand, due to the high rate of unemployment in Mufulira, people have no stable source of income to feed on and maintain their homes adequately. For example, water has been disconnected from many houses because of non-payment. Women participants during a group discussion and in individual interviews explained daily they and their children have to fetch water from neighbours, but mostly from the nearby stream. Those who depended on vegetable gardening could no longer continue because of the water problem in those residential areas.

\subsection{Ability to Maintain and Service Purchased Houses}

Interviews with officials showed that the government understood privatisation of public rental houses as a way of making people participate in development programs. Through government sale of houses, the people, even the poor, can participate in improving their welfare. By purchasing the house, the owner becomes responsible for its maintenance and improvement. The owners must make decisions concerning their property as they have the authority. However, having the means to purchase and maintain an individually owned house is a basis for sustainable homeownership. This entirely depends on the sound financial status of the individual house owners.

According to Hebert et al. (2013, p.7) posit that "the need to maintain the home also imposes financial risks on owners." The routine maintenance of houses such as painting the exterior or replacing the roof or heating system can lead homeowners to incur high costs that may be difficult for owners to afford. In this study, it was clear through interviews and observations that not many house owners have done repairs to their houses. Those who have managed to repair their houses are mainly those who are still in employment. Thus, housing rights become meaningful when the home-owners have means of maintaining and improving their houses. Although people feel proud to own houses, many of them fail to maintain or service or improve their houses. The house owners, particularly those who are unemployed, have not made the necessary repairs or renovations. Such as painting the walls, mending cracked walls, replacing broken windows, padlocks, leaking water pipes inside the house, electrical fittings or proper wiring, bathroom, toilet and fencing. Some of the house owners are not able to service their houses regularly through the payment of electricity bills, and water and sewage bill. Below is an illustration of how serious the maintenance problem is among the low-income groups, as reported during focus group discussions by a male respondent in his $40 \mathrm{~s}$, married with five children:

My house had part of its roof blown off by strong winds three years ago, but I have not made replacements due to financial difficulties. Even those who have put their house on rent cannot do repairs because the money they earn on renting goes to food and other necessities.

A middle-aged female respondent in a women's group firmly pointed out: 
It is not possible to repair things like toilets/bathrooms or broken windows or painting walls when we struggle to find money to feed our families. From the time our husbands were retrenched, we are literally struggling.

The house in plate 9.5 is an excellent example of a house not being maintained and its structure (toilet/bathroom in plate 9.6) these have not been maintained in a long time. According to the owner, the lady shown in plate 9.5 below, she moved into the house in the 1970s. As a sitting tenant, she bought it during the government sale of houses. The house has seen no repairs or painting since she moved in, and being a widow and unemployed, she has been unable to improve it even after she bought it.

In some places, even those who can afford to pay for water do not have water in their houses. This is because water pipes in the neighbourhood are stolen or vandalized after the council disconnected defaulting house owners. The council is not doing much to maintain the privatised areas. After privatisation, people are supposed to solve problems by paying private plumbers to repair leaking water pipes or sewage problems. The council does not have money to service these areas adequately. Since most council houses were sold out; land rates are the primary source of income for the council. The street roads are in a bad state, there are no street lights for security, and garbage is not collected regularly. With such considerations in mind, it is right to ascribe to Harrison (1995)'s perception of empowerment. He asserts that ownership of a house provides examples of potentially empowering forms of government support. At the same time, non-access to essential services such as safe water and sanitation can illustrate disempowerment.

Some house owners are having problems to settle their land rates and were not even aware that they were still expected to be paying land rates to the council after buying the houses. Before privatisation, most of the people were employed, and even then the housing was highly subsided as employers met a more significant percentage of the cost. Most of the home-owners at the moment have already accumulated bills for land rates from the time they bought their houses. Failure to settle land rates may lead to seizure of property or repossession of the houses. Since some house owners could not manage to maintain and service their houses, they have resold their houses and found themselves cheaper accommodation in shanty compounds since very few are willing to go back to the land to farm.

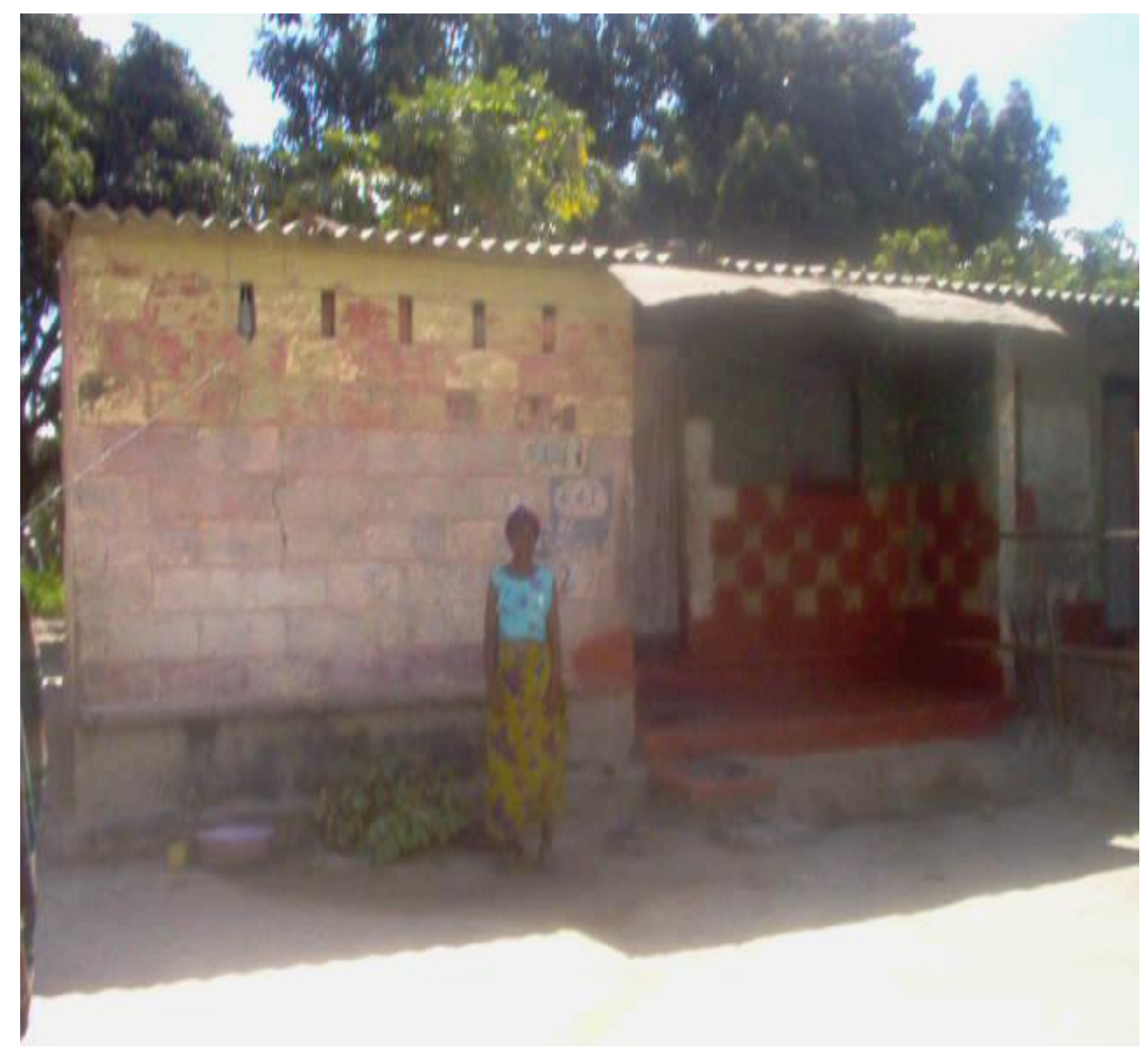

Plate9.5: Low-cost house

Source: Field Photo 


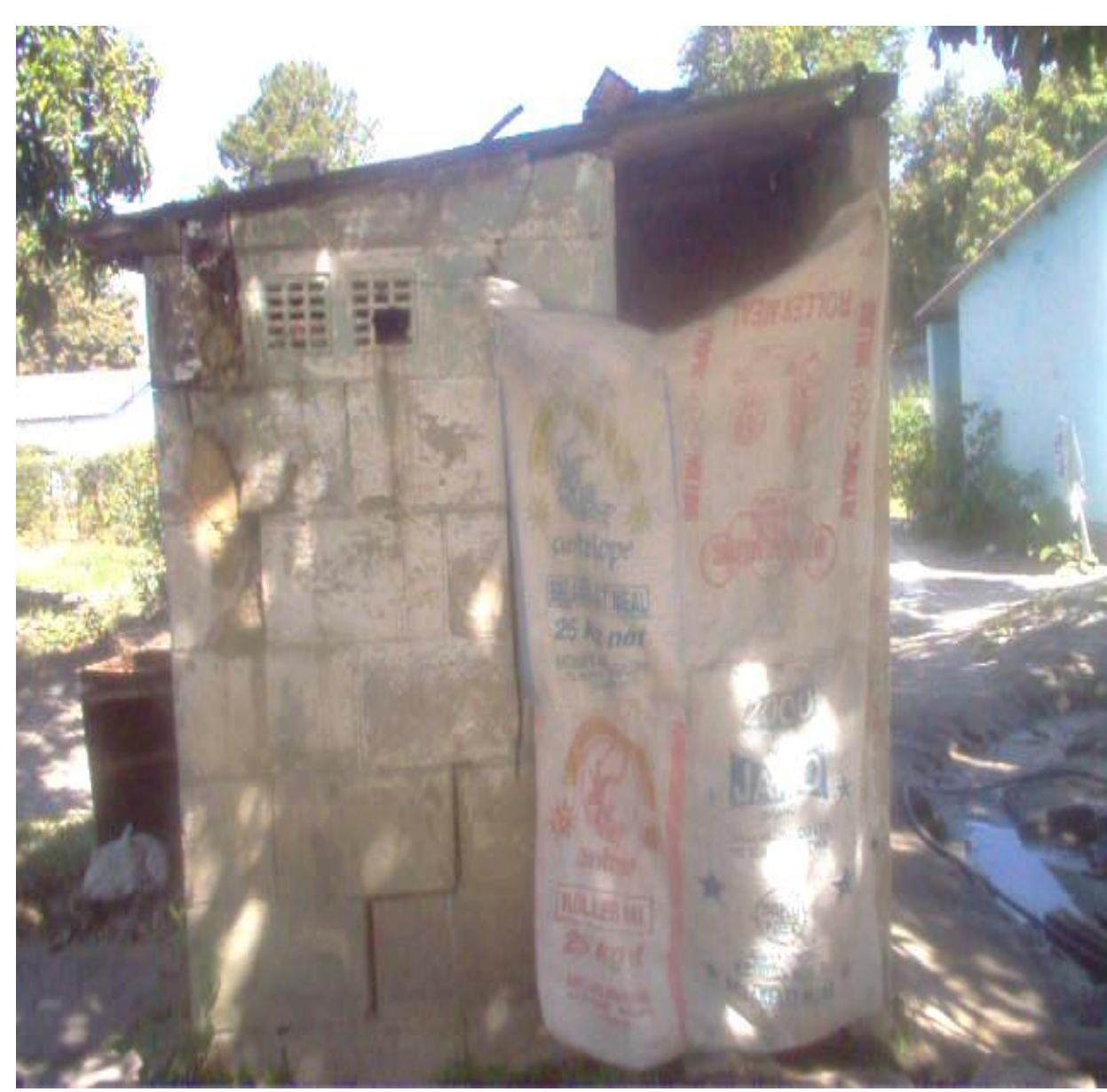

Plate9.6: Showing a toilet/bathroom

Source: Field photo

The lack of maintenance and improvement of most houses was very evident through observation during the study. Some people are making extensions in order to cater for their large families, but the building materials they are using are of inferior quality. Yet, the majority of the house owners would like to have their houses extended because most of the low-cost houses are small, one-bedroomed, with a sitting room and a kitchen, bathroom/toilet outside the house. The study argues that the size and nature of the house reveal much about people's comfort. Most of the families are very big, with family-sizes ranging from 4 to 10 people. There was a consensus among the respondents that extending their houses was needed. If they had an opportunity, they would be happy to have their houses extended in order to cater to their bigger families. The local authorities acknowledged the existence of poor quality structures in the residential areas like the one shown in plate 9.2 and 9.3. The council is threatening to demolish the structure because those who plan to make extensions must have their building plans approved by the council.

In some places, neighbourhoods are developing into shanty compounds. People have been empowered to some extent through house ownership. However, this kind of empowerment is not sustainable to the majority of the beneficiaries. There is a scenario where many structures of substandard quality have mushroomed. On the other hand, a few people, especially those who are still employed and those running big businesses are proud of owning houses and are doing all the necessary repairs and even making extensions with building materials of acceptable standards by the council. Below in plate 9.6 and plate 9.7 are photos of improved low-income houses. The owner of the house 9.7 invested his entire retirement package on renovating his house, and at the moment he has no money to enable him to take decent meals daily and to meet the school fees for his son who is at high school. He said that although he now owns a house of his own, was not sure about what the future holds for him as he no longer has any money to live on and continue maintaining his house. He still has not yet done the renovations for his bath/toilet room and painting the inside of his house. 


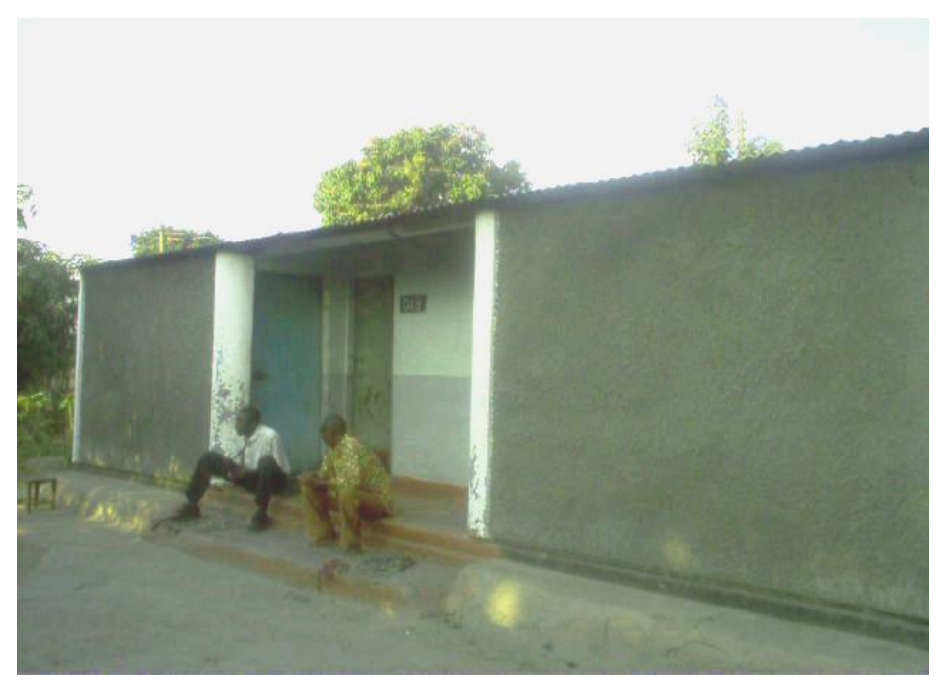

Plate9.7: Showing a partially improved low-cost house with the owner and son seated

Source: Field Photo

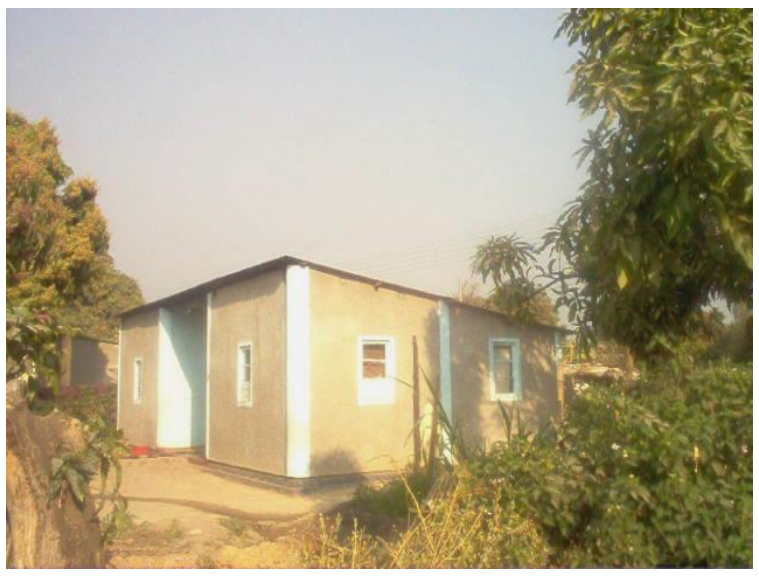

Plate9.8: Showing an improved Low-cost House

Source: Field Photo

Homeownership is an opportunity for people with stable incomes while it is a constraint for the unemployed. Regrettably, the benefits of home-ownership while widely perceived have not been universally realized among the low-income groups or the poor as this study has revealed. Retsina and Belseky (2002) describes the notion of home-ownership as being a construct as the benefits of owning a house are different for different individual groups of people. Kemeny (1981) strongly argues that home-ownership is a significant form of tenure in capitalist societies. Much of the appeal of owning a house lies in the fact that housing policies have been adopted which leave the minimal choice for most households as to which tenure they can realistically choose.

\section{CONCLUSION}

The economic impact of the sale of houses varied depending on individual circumstances. While some experienced positive changes in their economic status, others only had slight improvements, and for some, the changes were insignificant, or they just maintained their original status. In some cases, people became worse off. Generally, just the very fact that people had their own houses made them feel comfortable economically as it represented some economic value which could be converted into cash in times of need. The different ways in which people achieved changes in their economic status included re-selling the houses, subletting them for rent or being able to do some form of business from their house premises. In terms of maintenance and improving the houses they had bought, some new house owners have improved or extended their houses. This was particularly the case for those who are still in employment and can invest in their new properties. However, most of those in the low-income group cannot make improvements to their house due to financial constraints. The exercise of privatisation of public rental houses was not only empowering but also disempowering to some groups of individuals. Thus, the study concludes that the housing programme has mostly contributed 
to inequalities instead of empowering the poor. It is important to note that a lack of economic security caused many people to be homeless. Ownership of a house is only a temporary solution to economic security, as it rarely leads to meaningful economic empowerment for the vulnerable members of society. The right perspective demands that the state helps the homeless and poor people secure housing rights, by empowering them; bring to an end forced evictions; secure tenure rights; and promote equal access to housing. Besides, essential housing services such as water and sanitation must be accessible to the people.

\section{RECOMMENDATIONS}

Based on the study findings, the following are the recommendations to help policy-makers come up with workable strategies and implement housing projects which will meet the real housing needs of the most vulnerable members of the society.

- In order to realise the housing rights of vulnerable groups including those of women to access adequate housing, protection against violence and evictions, relevant policies and laws must be put in place and fully enforced to support the empowerment processes through participation.

- The home-ownership programme should have been accompanied by the creation of employment opportunities or other income-generating activities.

- The use of affordable local building materials should be demonstrated and promoted by the local authority to help low-income homeowners to upgrade their houses to approved or acceptable standards.

\section{REFERENCES}

[1] Lungu, Francis (2018). Dynamics around Zambia's Housing Deficit. Zambia Daily Mail, 29 May 2018.

[2] Central Statistical Office (CSO) (2015). Zambia 2015 Living Conditions Monitoring Survey Key Findings. Central Statistical Office, Lusaka.

[3] Saunders, P. (1990). A Nation of Home Owners. Unwin Hyman: London.

[4] Blunt, A. and Varley, A. (2004). 'Geographies of Home' in Cultural Geographies, 11:3-6. Arnold: London.

[5] United Nations (2001) Continuing Special Session on Implementation of Habitat Agenda, Assembly stresses shelter for All, Sustainable Settlements. www.un.org/news/press/doc/2001/GA9871.corr1.doc. $\mathrm{htm}-5 \mathrm{k}$.

[6] Andre, S \& Dewilde, C (2014). Homeownership and Support for Government Redistribution. Department of Sociology, Tilburg University, the Netherlands.

[7] Mbati-Mwengwe, C. C. (2001) Implementation of the Zambian Housing Policy: Empowerment through Homeownership www.hdm.ith.se/Training/postgrad/Ad/papers/2001/2pdf.

[8] Ministry of Local Government and Housing (MoLGH) (1996a). National Housing Policy. Government Printers: Lusaka.

[9] Bergeron, E (2019). Adequate Housing is a Human Right. Human Rights Magazine. 44(2).

[10] United Nations Development Programme (UNDP) (2003). Poverty Reduction and Human Rights: A Practical Note. UNDP: New York.

[11] Moser, C. and Norton, A. (2001). To Claim Our Rights: Livelihoods Security, Human Rights and Sustainable Development. Overseas Development Institute: London.

[12] Basila, C. (2019). Zambia's Implementation of the Housing Empowerment Programs in the Era of NeoLiberal Policies: Gains and losses, A case of Mufulira. International Journal of Multidisciplinary Research and Development, 6(11), pp.201-209.

[13] Basila, C. (2005). Zambia's Housing Scheme of the mid-1990s: Have the poor really been empowered? MA Thesis: Norwegian University of Science and Technology (NTNU).

[14] Schlyter, A. (2000). Privatisation of Council Housing in Lusaka, Zambia, Paper (draft) to the International Research Conference Housing in the $21^{\text {st }}$ century: Fragmentation and Reorientation. The Nordic Africa Institute: Uppsala.

[15] World Bank (2001). Countries: Zambia. August. www.worldbank.org.

[16] Central Statistical Office (2014). 2010 Census of population and housing: Copperbelt Province analytical report. Central Statistical Office.

[17] Saffira, Siavash. (2013). Alternative Development(s), or Alternative(s) to Development?: Challenges and Prospects for Genuine Alternative-building. In Nathan N. Andrews, Ernest Khalema, Temitope Oriola, and 
Isaac Odoom, eds., Africa Yesterday, Today \& Tomorrow: Exploring the Multi-dimensional Discourses on 'Development'. Newcastle, UK: Cambridge Scholars, (2013): 40-51.

[18] Pieterse, J. N. (2001). Development Theory: Deconstructions/Reconstructions. Sage Publications: London.

[19] Chattopadhyay Abhisek (2018). A Study on Status of Higher Education of Women and Economic Empowerment in India. The Research Journal of Social Sciences July 2018 9(7).

[20] Visvanathan, N., Duggan, L., Nisonoff, L., and Weigersma, N. (eds) (1997). The Women, Gender and Development Reader. ZED Books Ltd: London and New Jersey.

[21] Sikira A. N, Matekere T., Urassa J. K (2018). Engaging Men in Women's Economic Empowerment in Butiama District, Mara Region, Tanzania. Handbook of Research on Women's Issues and Rights in the Developing World. IGI Global: Hershey, PA.

[22] Domingo, Pilar (2013). Property rights and development: Property rights and social, political and economic empowerment. odi.org.

[23] Friedmann, J. (1992). Empowerment: The Politics of Alternative Development. Blackwell Publishers: Cambridge.

[24] Cresswell, J. W and Creswell, J. D (2018). Research Design: Qualitative, Quantitative, and Mixed Methods Approaches. SAGE Publications, Inc: London.

[25] Creswell, J. W. (1994). Research Designs: Qualitative and Quantitative Approaches. Sage Publications: London.

[26] Patton, M. Q. (1990). Qualitative Evaluation and Research Methods (2 ${ }^{\text {nd }}$ edition). Sage Publications: Newbury Park, CA.

[27] Mikkelsen, B. (1995). Methods for Development Work and Research. A Guide for Practitioners. Sage publications: New Delhi.

[28] Herbert, E.C, McCue, D.T. and Sanchez-Moyano, Rocio (2013). Is Homeownership Still an Effective Means of Building Wealth for Low-income and Minority Households? (Was it Ever?). Harvard University, Joint Center for Housing Studies.

[29] Retsina, N. P. and Belsky, E. S. (2002). 'Examing the Unexamined Goal' in Retsina, N. P. and Belsky, E. S. Low-income Homeownership. The Brooking Institution Press: Washington, D. C. 1-14.

[30] Harrison, M. L. (1995). Housing, 'Race', Social Policy and Empowerment. Ashgate: Aldershot.

[31] Schuler, M. A. (ed) (1995). From Basic Needs to Basic Rights. Institute for Women, Law and Development: Washington, DC.

[32] Kemeny, J. (1981). The Myth of Home Ownership: Private versus Public choices in Housing Tenure. Routledge: London.

Citation: Christcola Basila, Kennedy Sialoombe. "Does House Ownership Entail Economic Empowerment among the Low-Income People In Zambia?". International Journal of Humanities Social Sciences and Education (IJHSSE), vol. 7, no.1, 2020, pp. 125-140. doi: http://dx.doi.org/10.20431/2349-0381.07 01014.

Copyright: (C) 2020 Authors. This is an open-access article distributed under the terms of the Creative Commons Attribution License, which permits unrestricted use, distribution, and reproduction in any medium, provided the original author and source are credited. 